\title{
Microbial Metabolism \\ of Amino Ketones: D-1-Aminopropan-2-ol and Aminoacetone Metabolism in Escherichia coli
}

\author{
By D. A. LOWE* AND J. M. TURNER \\ Department of Biochemistry, University of Liverpool, \\ P.O. Box 147, Liverpool, L69 3BX
}

(Accepted for publication 16 June 1970)

\begin{abstract}
SUMMARY
Aminoacetone was formed from D- or L-I-aminopropan-2-ol, or both, by a variety of micro-organisms. An oxidoreductase capable of oxidizing D-I-aminopropan-2-ol to aminoacetone was purified 38-fold from Escherichia coli. It was inactive with L-I-aminopropan-2-ol, L-threonine and DL-glycerolI-phosphate. It was highly active with a variety of diols and hydroxyketones and not narrowly specific as reported by other workers (Decker \& Swain, 1968). The effect of growth conditions on activity suggested involvement in mono- or di-hydroxyacetone metabolism. Although D-I-aminopropan2-ol oxidation was demonstrated in crude extracts of a number of other bacteria, a relationship between L-threonine and D-I-aminopropan-2-ol dehydrogenases and vitamin $B_{12}$ biosynthesis does not appear likely.
\end{abstract}

\section{INTRODUCTION}

A previous study with Escherichia coli showed that NAD-dependent oxidoreductase activities towards L-threonine, and both L- and D-I-aminopropan-2-ol were present in extracts and the properties of the first two enzymes were described (Turner, 1967). Aminoacetone was the product in both cases. The present paper describes the properties of a partially purified oxidoreductase acting on D-I-aminopropan-2-ol also to form aminoacetone. Interest in this enzyme arises because of its possible involvement in the reduction of aminoacetone to give D-I-aminopropan-2-ol which then may be incorporated into vitamin $B_{12}$ (Turner, I966), although it still remains to be demonstrated that it is the D-isomer which is the product of aminoacetone reduction in this organism. Some support for this hypothesis comes from the work of Krasna, Rosenblum \& Sprinson (1957), who showed that the incorporation of isotope from [ $\left.{ }^{15} \mathrm{~N}\right]$-L-threonine into the D-I-aminopropan-2-ol fragment of vitamin $\mathrm{B}_{12}$ occurred in Streptomyces griseus.

Some of this work has been summarized previously in a preliminary note (Lowe \& Turner, 1968).

\section{METHODS}

Micro-organisms and media. Escherichia coli, type I (National Collection of Industrial Bacteria (NCIB) no. 8II4) was maintained and cultured as described previously (Turner, 1966). Pseudomonas strains 8/IX and DL 8A were isolated by enrichment

* Present address: Department of Microbiology, University of Alberta, Edmonton, Alberta, Canada. 
culture on DL-I-aminopropan-2-ol as the main carbon and nitrogen source, as described by Higgins, Pickard \& Turner (1968). Other micro-organisms were obtained from the NCIB, Aberdeen, Scotland, the National Collection of Plant Pathogenic Bacteria (NCPPB), Hatching Green, Harpenden, Hertfordshire, or were laboratory strains. All micro-organisms were maintained as slope or stab cultures on nutrient agar $(2.5 \%, \mathrm{w} / \mathrm{v})$. Some vitamin $\mathrm{B}_{12}$-producing micro-organisms (see Table 7 ) were grown on peptone-yeast extract medium, modified from that described by Hall, Benedict, Wiesen, Smith \& Jackson (I953) and consisting of $10 \mathrm{~g}$. glucose, 3 g. yeast extract, 3 g. soya peptone, I g. $\mathrm{CaCO}_{3}, \mathrm{I} \cdot 5$ g. $\mathrm{K}_{2} \mathrm{HPO}_{4}$, I g. $\mathrm{KH}_{2} \mathrm{PO}_{4}$ and Io $\mathrm{mg}$. $\mathrm{CoSO}_{4} \cdot 7 \mathrm{H}_{2} \mathrm{O}$ made up to $\mathrm{I} 1$. with glass-distilled water. Other micro-organisms were grown on nutrient broth medium (Oxoid no. 2) or simple basal salts media containing 7 g. $\mathrm{K}_{2} \mathrm{HPO}_{4}, 3$ g. $\mathrm{KH}_{2} \mathrm{PO}_{4}$, I.2 g. $\mathrm{Na}_{2} \mathrm{SO}_{4} \cdot \mathrm{IOH}_{2} \mathrm{O}$, O.I g. $\mathrm{MgSO}_{4} \cdot 7 \mathrm{H}_{2} \mathrm{O}$, I g. $\left(\mathrm{NH}_{4}\right)_{2} \mathrm{SO}_{4}$ and 5 g. of various carbon sources per litre. Synthetic media were adjusted to $\mathrm{pH} 7^{\circ} \mathrm{O}$ prior to sterilization. Carbohydrates were autoclaved separately.

Preparation of enzyme extracts. Bacteria were harvested in the exponential growth phase and extracts prepared as described by Turner (1966).

Measurement of aminoacetone production and utilization by washed suspensions of bacteria. Aminoacetone production and utilization were measured as described by Higgins et al. (1968). The partially resolved amino alcohols were used as substrates for aminoacetone production.

Uptake of radioactive $\left[3^{-14} C\right]-D L-I$-aminopropan-2-ol by growing and resting bacteria. Washed suspensions of Escherichia coli were incubated at $4 \mathrm{mg}$. dry wt/ml. with $0.3 \mathrm{mg}$. of [ $\left.3^{-14} \mathrm{C}\right]$-DL-I-aminopropan-2-ol (0.085 $\left.\mathrm{mCi} / \mathrm{mmole}\right)$ and $0.5 \mathrm{mmole} \mathrm{K}_{2} \mathrm{HPO}_{4}+$ $\mathrm{KH}_{2} \mathrm{PO}_{4}$ buffer, $\mathrm{pH} 7{ }^{\circ}$, in $5 \mathrm{ml}$. at $30^{\circ}$ with shaking. Samples of culture or bacterial suspensions were then filtered through $0.45 \mu$ Millipore membrane filters (Millipore Filter Corporation, Bedford, Massachusetts, U.S.A.). The bacteria were washed with $0 \cdot I M$-phosphate buffer before attaching the filters to planchets and drying. Samples of the combined filtrates and washings were also dried on planchets and examined for radioactivity. Radioactivity was measured using a Nuclear Chicago Model D 47 Gas Flow Detector (Nuclear Chicago, Des Plaines, Illinois, U.S.A.), which had a calculated counting efficiency of $3 \mathrm{I} \%$.

Measurement of $L$-threonine, $D$ - and $L$-I-aminopropan-2-ol dehydrogenase activities in enzyme extracts. D- and L-I-aminopropan-2-ol dehydrogenase activities were assayed in reaction mixtures containing $50 \mu$ mole D- or L-I-aminopropan-2-ol, either as the optically pure bases or partially resolved tartrates, $500 \mu$ mole diethanolamine + $\mathrm{HCl}$ buffer $\mathrm{pH} 9.6,10 \mu$ mole $\mathrm{NAD}^{+}$, and $0.5 \mathrm{mg}$. protein (dialysed crude extract) or $50 \mu \mathrm{g}$. of partially purified enzyme preparation, in a total volume of $\mathrm{I} \cdot 6 \mathrm{ml}$. Unless otherwise indicated, $30 \mu$ mole $\left(\mathrm{NH}_{4}\right)_{2} \mathrm{SO}_{4}$ was included in the D-I-aminopropan-2-ol dehydrogenase assay mixture. Reactions were started by addition of enzyme to the otherwise complete reaction mixtures equilibrated at $37^{\circ}$. All incubations were for $20 \mathrm{~min}$. at $37^{\circ}$. Reactions were stopped with $0.3 \mathrm{ml} .25 \%(\mathrm{w} / \mathrm{v})$ trichloroacetic acid. After centrifuging, $\mathrm{I} \cdot 0 \mathrm{ml}$. of supernatant fluid was assayed for aminoacetone. When assaying for L-threonine dehydrogenase, 100 $\mu$ mole of $\mathrm{L}$-threonine was used as substrate with $500 \mu$ mole tris $+\mathrm{HCl}$ buffer $\mathrm{pH} 9 \cdot 0$.

Assay of aminoacetone and protein. Assays were carried out colorimetrically as described previously (Turner, 1966).

Spectrophotometric enzyme assays. D-I-Aminopropan-2-ol and secondary alcohol- 
dependent reduction of $\mathrm{NAD}^{+}$was measured in reaction mixtures containing $750 \mu$ mole diethanolamine $+\mathrm{HCl}$ buffer $\mathrm{pH}_{9 \cdot 6}$, io $\mu$ mole $\mathrm{NAD}^{+}, 50 \mu$ mole secondary alcohol substrate, $50 \mu$ mole $\left(\mathrm{NH}_{4}\right)_{2} \mathrm{SO}_{4}$ and 0.02 to $0.50 \mathrm{mg}$. protein in a total volume of $2.5 \mathrm{ml}$. Aminoacetone and hydroxyketone reductase activities were carried out using $750 \mu$ mole sodium acetate + acetic acid (or 3,3'-dimethylglutaric acid $+\mathrm{NaOH}$ ) buffer pH 6.0 , ro $\mu$ mole aminoacetone or $2.5 \mu$ mole hydroxyketone, $0.75 \mu$ mole NADH or NADPH, $50 \mu$ mole $\left(\mathrm{NH}_{4}\right)_{2} \mathrm{SO}_{4}$ and 0.02 to $0.50 \mathrm{mg}$. protein in $2.5 \mathrm{ml}$. total volume. Substrate or cofactor was omitted from the compensating cells and the reactions were started by the addition of enzyme to otherwise complete reaction mixtures equilibrated at $37^{\circ}$.

Enzymic activities are expressed as m $\mu$ moles of NADH produced, or NADH/ NADPH oxidized/mg. protein $/ \mathrm{min}$. at $37^{\circ}$.

\section{Purification of D-I-aminopropan-2-ol-aminoacetone oxidoreductase activity}

(a) Heat treatment. Crude extract was adjusted to $8 \mathrm{mg}$. protein $/ \mathrm{ml}$., heated for $10 \mathrm{~min}$, and precipitated protein was removed by centrifuging at $10,000 \mathrm{~g}$ to give a clear supernatant fluid.

(b) Molecular exclusion chromatography. Portions of heat-treated enzyme were further purified by gel filtration on Bio-Gel P-300 as described by Turner (1967). Enzyme activity was eluted immediately after the void volume $\left(V_{e} / V_{o}=\mathrm{I} \cdot 3\right)$. The active fractions were combined for further purification.

(c) Ion-exchange cellulose chromatography. The enzyme was next adsorbed on 30 g. DEAE cellulose 'Chromedia DE 52' (pre-swollen) previously equilibrated with $0.02 \mathrm{M}$-phosphate buffer $\mathrm{pH} 7.0$ at $4^{\circ}$. Protein was eluted from the cellulose by a gradient of 0 to $\mathrm{I} \cdot \mathrm{OM}-\mathrm{NaCl}$ in $0.02 \mathrm{M}$-phosphate buffer $\mathrm{pH} 7.0$, at a flow rate of about $30 \mathrm{ml}$./h. Under these conditions enzyme activity was eluted by 0.35 to $0.40 \mathrm{M}-\mathrm{NaCl}$.

\section{Preparation of optically active $\mathrm{I}$-aminopropan-2-ols}

(a) Partially resolved $D$-(-)-I-aminopropan 2-ol $D$-(-)-tartrate. This was prepared by the procedure of Sullivan (I963) as described by Turner (1967), except that $L(+)$ tartaric acid was replaced by $\mathrm{D}(-)$ tartaric acid. The optical rotation of the recrystallized D-(-)-I-aminopropan-2-ol D-(-)-tartrate dihydrate, was $[\alpha]_{D}^{22.5}=-3 \mathrm{I} \cdot 5^{\circ}$ (C. 5 and 10 in water).

(b) Optically pure $D$ - and L-I-aminopropan-2-ol. The method used was a modification of that described by Chatelus (I964). For the preparation of D-I-aminopropan-2-ol, Io $\mathrm{g}$. of L-threonine and $66 \mathrm{~g}$. of freshly distilled acetophenone (mole ratio 3:20) were heated with constant stirring at $130^{\circ}$ for $7 \mathrm{~h}$. The resultant deep-red solution (Schiff's base) was hydrolysed by shaking with four $50 \mathrm{ml}$. volumes of $3 \mathrm{~N}-\mathrm{HCl}$ at $50^{\circ}$ to release the base. The combined aqueous fractions were dried. The hydroscopic residue was dissolved in the minimum of warm dry absolute ethanol. After cooling the solution, D-I-aminopropan-2-ol $\mathrm{HCl}$ was precipitated by adding 7 vol. dry diethyl ether and removed by filtration. The crystals were dissolved in ethanol and re-precipitated by ether to yield a flakey white product which was stored under vacuum over a desiccant. The product had a m.p. of $97^{\circ}$, cf. authentic DL-I-aminopropan-2-ol m.p. $96^{\circ}$; and exhibited $[\alpha]_{D}^{22.5}=-58^{\circ}$ (C. 2 and 5 in water) and $[\alpha]_{\mathrm{D}}^{22.5}=-33^{\circ}$ (C. I and 3 in methanol), cf. $[\alpha]_{\mathrm{D}}^{25}=-3 \mathrm{I} \cdot 5^{\circ}$ (C. I in methanol), Clark, 
Jones, Raich \& Folkers (1954), and $[\alpha]_{\mathrm{D}}=-58^{\circ}$ (unknown solvent), Karrer \& Klarer (1925), reported for synthesized D-I-aminopropan-2-ol $\mathrm{HCl}$.

Similarly, L-I-aminopropan-2-ol $\mathrm{HCl}$, prepared from D-threonine, exhibited $[\alpha]_{\mathrm{D}}^{22.5}=+38^{\circ}$ (C. 5 in water). Optical rotation values were determined as described previously (Turner, 1967 ).

Detection of I-aminopropan-2-ol formation. Aminoacetone (Io $\mathrm{mM}$ ) and NADH $(0.4 \mathrm{~mm})$ were incubated at $37^{\circ}$ with purified enzyme $(0.3 \mathrm{mg} . / \mathrm{ml}$.) in phosphate buffer, pH $6(50 \mathrm{~mm})$, in the presence of $\left(\mathrm{NH}_{4}\right)_{2} \mathrm{SO}_{4}(20 \mathrm{~mm})$. After I to $2 \mathrm{~h}$., reaction mixtures were deproteinized and applied to a column of BioRex 70 cation exchange

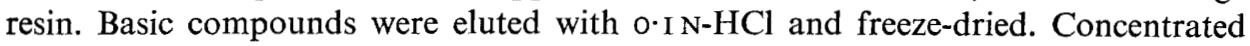
solutions were streaked on to thin-layer cellulose plates and chromatographed in butan-I-ol+propionic acid + water $(47+22+3 \mathrm{I}$, by vol.). Aminopropanol was detected as a distinct ninhydrin-positive band running slightly ahead of aminoacetone ( $R_{F^{*}}$ values 0.4 and 0.3 respectively).

Chemicals. The sources of chemicals were those described previously by Turner (1967) and Higgins et al. (1968). In addition, D-tartaric acid, meso-butan-2,3-diol, DL-propan-1,2-diol, hydroxyacetone and DL-acetoin were obtained from British Drug House Ltd, Poole, Dorset; D-threonine, DL-I-bromopropan-2-ol and DL-I-fluoropropan-2-ol from K and K Laboratories Inc., Plainview, New York, U.S.A.; soya peptone L 44 and yeast extract L 2 I from the Oxoid Division of Oxo Ltd, London; dihydroxyacetone from Calbiochem. Inc., Los Angeles, California, U.S.A.; DE 52 Chromedia ion-exchange cellulose from $\mathrm{H}$. Reeve Angel and Co. Ltd, London. $\left[\mathrm{U}-{ }^{14} \mathrm{C}\right]-\mathrm{L}-\mathrm{Th}$ reonine was purchased from The Radiochemical Centre, Amersham, Buckinghamshire. All chemicals were of analytical reagent grade, or of highest quality available commercially.

\section{RESULTS}

Aminopropanol and aminoacetone metabolism by intact bacteria

Previous results had shown that Escherichia coli was unable to utilize the nitrogen of DL-I-aminopropan-2-ol for growth on a variety of carbon sources (Turner, 1967). The same results were obtained in the present study using aminoacetone. The ability of washed suspensions of $E$. coli to form the amino ketone from DL-I-aminopropanol was shown to be due to the oxidation of only the L-isomer (Table I). Some microorganisms among those tested were found, however, to produce aminoacetone from both stereo-isomers (Table I).

The possible utilization of aminopropanols for biosynthetic rather than catabolic purposes by Escherichia coli was studied by adding [3-14C]-DL-I-aminopropan-2-ol ( $0.66 \mu \mathrm{Ci}, 4.2 \mu$ mole) to freshly inoculated $\mathrm{I} 0 \mathrm{ml}$. cultures of $E$. coli, growing either on nutrient broth or on succinate basal salts media. Only about $6 \%$ of the radioactivity was incorporated into bacterial substance within 36 to $60 \mathrm{~h}$. In contrast, micro-organisms capable of growth on DL-I-aminopropan-2-ol, e.g. Achromobacter sp. P6 (Gottlieb \& Mandel, 1959) and Pseudomonas sp. NCIB $885^{8}$ (Higgins et al. I968), incorporated about $86 \%$ of the radioactivity under the same conditions. Washed suspensions of E. coli, grown on a variety of media, utilized [ $\left.3^{-14} \mathrm{C}\right]-\mathrm{DL}-\mathrm{I}$-aminopropan2-ol only after a lag of about $10 \mathrm{~h}$. Virtually all the radioactivity was taken up by the organism within $24 \mathrm{~h}$. and no trace of radioactive products was detectable in suspension media. Suspensions of broth-grown bacteria utilized aminoacetone immediately at 
rates of $\mathrm{I}$ to $2 \mathrm{~m} \mu \mathrm{moles} / \mathrm{mg}$. dry $\mathrm{wt} / \mathrm{min}$. at $30^{\circ}$ and $\mathrm{pH} 7$. Aminoacetone uptake was decreased $50 \%$ by an equimolar amount of L-I-aminopropan-2-ol whereas the D-isomer lowered uptake by only $5 \%$. Cultures growing on broth also utilized aminoacetone at slow rates.

Table 1. Aminoacetone production from $D$ - and L-I-aminopropan-2-ol by washed-cell suspensions of micro-organisms

Micro-organisms were grown on nutrient broth, or DL-I-aminopropan-2-ol medium (values in parentheses), and aminoacetone production by suspensions was measured as described in the Methods section.

Micro-organism

Achromobacter anitratum

Aeromonas liquefaciens

Erwinia carotovora

Escherichia coli, type I

Klebsiella aerogenes, type I

Proteus vulgaris

Pseudomonas aeruginosa

Pseudomonas sp.

Pseudomonas sp.

Pseudomonas sp.

Pseudomonas $\mathrm{sp}$.
Aminoacetone production (m $\mu$ moles/ mg. dry wt $/ \mathrm{min}$. at $30^{\circ}$ ) from

$\overbrace{\text { D-Aminopropanol* }}^{*}$ L-Aminopropanol $\uparrow$

Laboratory
Laboratory
NCPPB I 280
NCIB 8 I I4
NCIB 4I 8
Laboratory
NCIB 8293
NCIB 8194
NCIB 8858
8/IX $\$$
DL 8 A $\ddagger$

0

$5 \cdot 0$

0

6.I $5 \cdot 2$

0

$6 \cdot 2 \quad 3 \cdot 2$

$0.4 \quad 0.7$

$0.7(0.2) \quad 0.9(8.9)$

$0.2(-) \quad I \cdot 2(13 \cdot 2)$

$7 \cdot 5(0 \cdot 6) \quad 3 \cdot 2(10 \cdot 4)$

* Composition $82 \%$ D-I-aminopropan-2-ol, I $8 \%$ L-I-aminopropan-2-ol.

+ Composition $88 \%$ L-I-aminopropan-2-ol, I $2 \%$ D-I-aminopropan-2-ol.

$\ddagger$ Isolated in this laboratory for ability to grow on DL-I-aminopropan-2-ol.

\section{Table 2. Effect of activators and inhibitors on D-I-aminopropan-2-ol dehydrogenase activity}

Activity was measured colorimetrically as described in the Methods section, except that $\left(\mathrm{NH}_{4}\right)_{2} \mathrm{SO}_{4}$ was omitted from reaction mixtures in Expt. I.

Addition

None

Thioglycollate

Cysteine

2-Mercaptoethanol

$\left(\mathrm{NH}_{4}\right)_{2} \mathrm{SO}_{4}$

$\mathrm{Na}_{2} \mathrm{SO}_{4}$

$\mathrm{K}_{2} \mathrm{SO}_{4}$
Concentration

(mM)

Experiment

DL-Serine

DL-I-Dimethylaminopropan-2-ol

Ethan-I,2-diol

DL-3-Fluoro-I-aminopropan-2-ol

Glycerol

DL-I-Fluoropropan-2-ol

Propan-1,3-diol

meso-Butan-2,3-diol

DL-I-Bromopropan-2-ol

DL-Propan-I,2-diol

Experiment 2
Activity

$(\%)$

I0O

83

$8 \mathrm{I}$

$4^{8}$

200

I 40

103

9 I

90

86

58

58

57

52

43

17 


\section{D-I-Aminopropan-2-ol oxidation by cell-free extracts}

The NAD+-dependent oxidation of D-I-aminopropan-2-ol to aminoacetone was assayed colorimetrically (see Methods section). Under optimum conditions, activities of 12 to $15 \mathrm{~m} \mu$ moles aminoacetone formed $/ \mathrm{mg}$. protein $/ \mathrm{min}$. at $37^{\circ}$ were found in fresh extracts. Aminoacetone reductase activity could not be measured accurately in crude extracts due to the presence of high NADH oxidase activity.

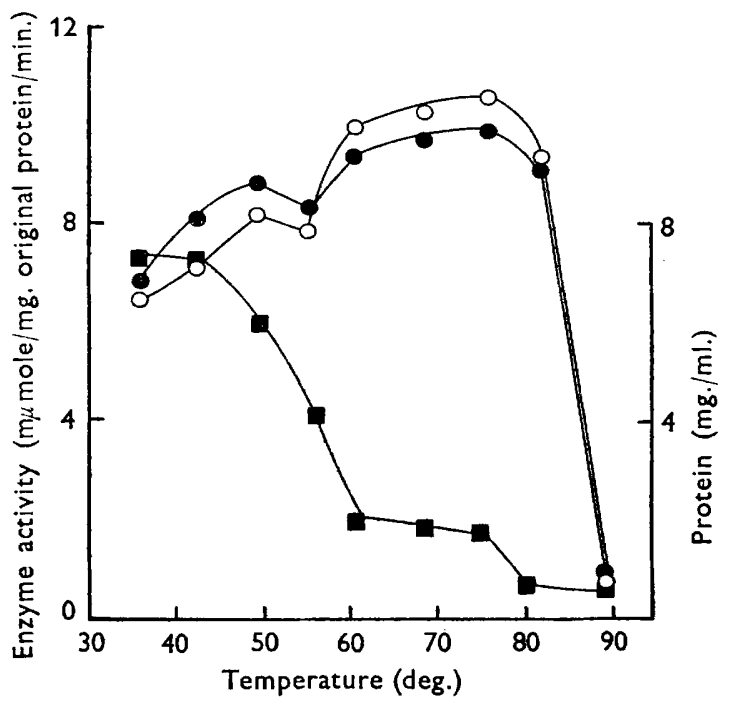

Fig. I. Heat-treatment of crude cell-free extracts of Escherichia coli. Aliquots of crude cell-free extract, adjusted to $8 \mathrm{mg}$. protein $/ \mathrm{ml}$, were held at various temperatures for $\mathrm{I}$ min. After removing the precipitated protein by centrifuging, supernatants were assayed for D-I-aminopropan-2-ol dehydrogenase activity $(O)$ colorimetrically, DL-propan-I,2-diol dehydrogenase activity $(\bullet)\left(\times \frac{1}{8}\right.$ given scale) spectrophotometrically, and protein content $(\boldsymbol{\square})$ as described in Methods. Enzyme activities are expressed in relation to the original protein concentration of untreated extract.

\section{Table 3. Partial purification of D-I-aminopropan-2-ol dehydrogenase}

Extracts from Escherichia coli grown on nutrient broth were fractionated as described in Methods.

\begin{tabular}{cccccc}
\multicolumn{1}{c}{ Fraction } & $\begin{array}{c}\text { Volume } \\
(\mathrm{ml})\end{array}$ & $\begin{array}{c}\text { Protein } \\
(\mathrm{mg} / \mathrm{ml})\end{array}$ & $\begin{array}{c}\text { Enzyme activity } \\
(\mathrm{m} \mu \mathrm{moles} / \mathrm{mg} . \\
\text { protein/min.) }\end{array}$ & $\begin{array}{c}\text { Total } \\
\text { units } \\
(\mathrm{IU})\end{array}$ & $\begin{array}{c}\text { Activity ratio } \\
\text { D-I-aminopropan-2-ol } \\
\text { DL-propan-I,2-diol }\end{array}$ \\
Crude extract & 20 & 19 & 12 & 4560 & 0.15 \\
Heat-treated & 20 & 4.7 & 46 & 4300 & 0.15 \\
BioGel P-300 & 70 & 0.45 & 144 & 4530 & 0.14 \\
DE 52 cellulose & 25 & 0.14 & 178 & 590 & 0.14 \\
Peak fraction & 3 & 0.12 & 450 & 162 & 0.14
\end{tabular}

The enzyme was activated by a number of monovalent cations, but inhibited by sulphydryl compounds and more markedly by substrate analogues (Table 2). Substances with little or no effect at $5 \mathrm{mM}$ included AMP, ADP, ATP, iodoacetate and glutathione. 
D-I-Aminopropan-2-ol dehydrogenase was remarkably stable to heat: heating at $70^{\circ}$ for 10 min. caused an increase in activity, as well as purification due to protein precipitation (Fig. I).

\section{Purification and properties of an oxidoreductase acting on D-I-aminopropan-2-ol and aminoacetone}

Purification was carried out as a preliminary to studies on substrate specificity and content of aminoacetone reductase activity (Table 3). The relative activities of D-I-aminopropan-2-ol and DL-propan-1,2-diol remained constant during 38-fold purification. During exclusion chromatography on Bio-Gel P-300, the oxidoreductase was completely separated from L-threonine and L-I-aminopropan-2-ol dehydrogenases. The enzyme was eluted immediately after the initial nucleoprotein indicating a mol. wt of about 300,000 (see Turner, 1967).

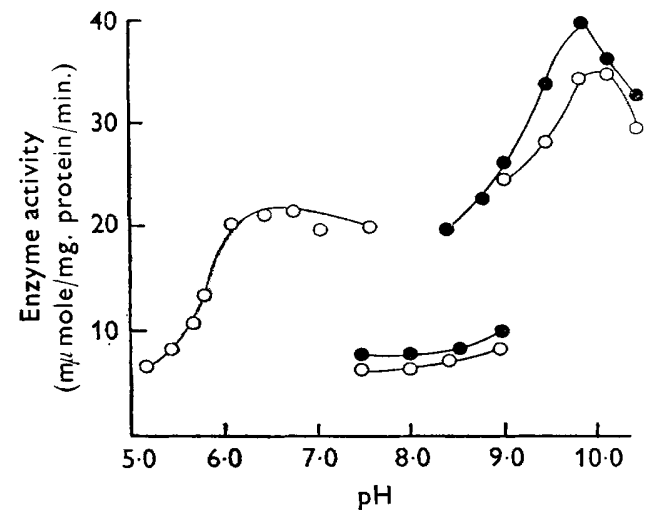

Fig. 2

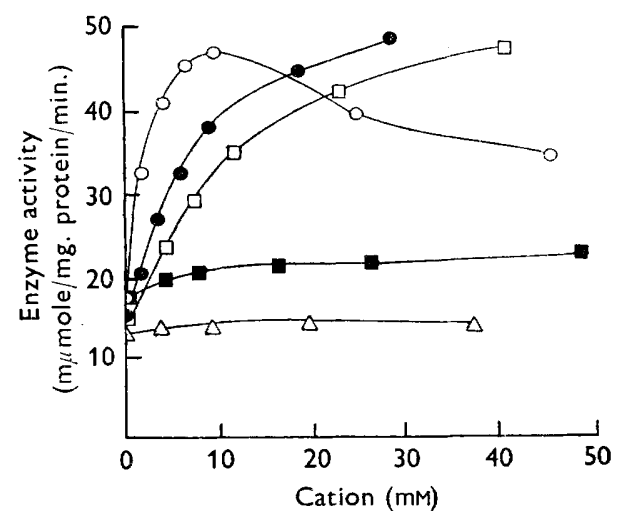

Fig. 3

Fig. 2. Effect of pH and buffers on D-I-aminopropan-2-ol and DL-propan-I,2-diol dehydrogenase activity. Enzyme activities in partially purified preparations were measured spectrophotometrically as described in Methods, although in the absence of $\left(\mathrm{NH}_{4}\right)_{2} \mathrm{SO}_{4}$ : $\mathrm{D}-\mathrm{I}$ aminopropan-2-ol dehydrogenase activity $(\mathrm{O})$, DL-propan-1,2-diol dehydrogenase activity

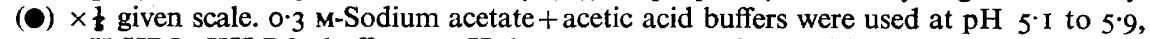
$0.3 \mathrm{M}^{-\mathrm{K}_{2}} \mathrm{HPO}_{4}-\mathrm{KH}_{2} \mathrm{PO}_{4}$ buffers at $\mathrm{pH} 6.0$ to $7.5,0.3 \mathrm{M}$-tris $+\mathrm{HCl}$ buffers at $\mathrm{pH} 7.4$ to 9.0 and $0.3 \mathrm{M}$-diethanolamine $+\mathrm{HCl}$ buffers at $\mathrm{pH} 8 \cdot 5$ to $\mathrm{IO} \cdot 2$.

Fig. 3. D-I-Aminopropan-2-ol dehydrogenase activation by monovalent cations. Activity in partially purified enzyme preparation was assayed colorimetrically as described in Methods, except that $\left(\mathrm{NH}_{4}\right)_{2} \mathrm{SO}_{4}$ in the incubation mixtures was replaced by $\mathrm{Li}_{2} \mathrm{SO}_{4}(\bullet)$, $\left(\mathrm{NH}_{4}\right)_{2} \mathrm{SO}_{4}(\mathrm{O}), \mathrm{Na}_{2} \mathrm{SO}_{4}(\mathrm{D}), \mathrm{K}_{2} \mathrm{SO}_{4}(\mathbf{E})$ or $\mathrm{Rb}_{2} \mathrm{SO}_{4}(\triangle)$.

PH optima. Optimum activity for the oxidation of either D-I-aminopropan-2-ol or DL-propan-1,2-diol with $\mathrm{NAD}^{+}$occurred at $\mathrm{pH} 9.8$ in diethanolamine $+\mathrm{HCl}$ buffer. Dehydrogenase activities were markedly lower in tris $+\mathrm{HCl}$ buffer (Fig. 2), particularly in the absence of $\mathrm{NH}_{4}{ }^{+}$. For the reduction of aminoacetone and hydroxyacetone with either NADH or NADPH, optimum activity was at $\mathrm{pH} 6 \cdot 0$.

Cation activation. The activity of the enzyme was stimulated by $\mathrm{NH}_{4}{ }^{+}, \mathrm{Li}^{+}$and $\mathrm{Na}^{+}$ at about 10, 50 and $100 \mathrm{~mm}$ respectively (Fig. 3). These effects, which were not additive, occurred with all substrates tested (see below). Cations were equally effective in both directions of the oxidoreductase. 
Substrate and cofactor specificities. Broad substrate specificity was found (Table 4). Inactive as substrates were L-threonine, L-serine, DL-2-hydroxy-2-phenylethylamine and DL-glycerol-I-phosphate. In the alcohol oxidation direction, activity with NADP+ was only $3 \%$ of that with $\mathrm{NAD}^{+}$. With the reduction of aminoacetone and other ketones, NADPH was at least $60 \%$ as active as NADH at the optimum concentrations of 0.3 to $0.4 \mathrm{~mm}$, but its relative activity was higher at higher (inhibitory) cofactor
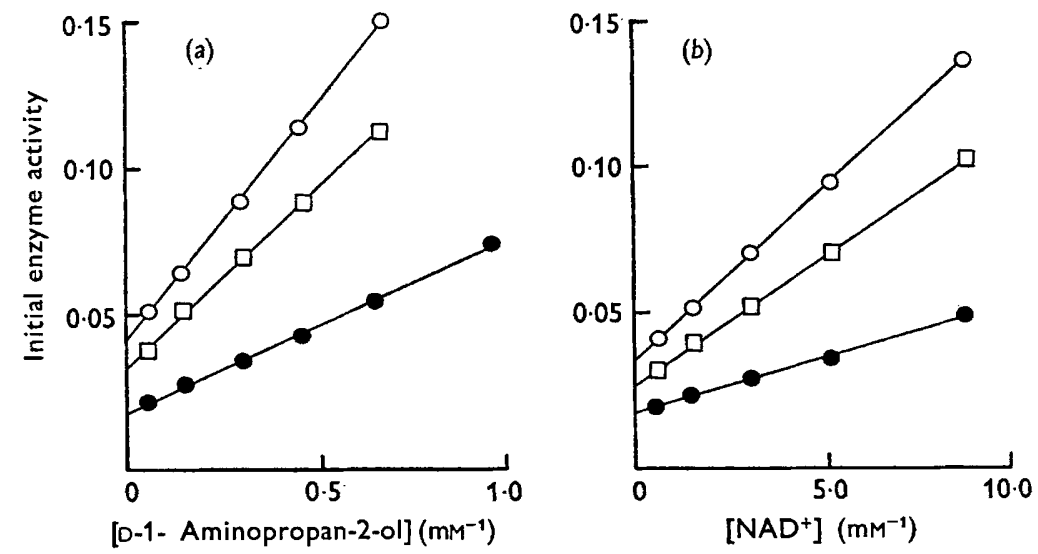

Fig. 4. Double reciprocal plots showing the effect of $\mathrm{NH}_{4}{ }^{+}$on D-I-aminopropan-2-ol dehydrogenase activity. Activity in partially purified enzyme preparation from Escherichia coli was assayed colorimetrically as described in Methods except where noted. (a) Incubation mixtures contained $2 \mu$ mole $\mathrm{NAD}^{+}$with $\mathrm{D}$-I-aminopropan-2-ol from I.0 to $20.0 \mu$ moles in presence of $\left(\mathrm{NH}_{4}\right)_{2} \mathrm{SO}_{4}$ at I mM (b) and $20 \mathrm{~mm}(\mathrm{O})$. $\mathrm{No}\left(\mathrm{NH}_{4}\right)_{2} \mathrm{SO}_{4}$ control (O). (b) Incubation mixtures contained $20 \mu$ mole $\mathrm{D}$-I-aminopropan-2-ol with $\mathrm{NAD}^{+}$from 0.1 to $2 \cdot 0 \mu$ moles in the presence of $\left(\mathrm{NH}_{4}\right)_{2} \mathrm{SO}_{4}$ at $\mathrm{I} \mathrm{mM}(\square)$ and $20 \mathrm{mM}(\mathrm{O})$. No $\left(\mathrm{NH}_{4}\right)_{2} \mathrm{SO}_{4}$ control (O).

Table 4. Substrate specificity of enzyme acting on D-I-aminopropan-2-ol

Substrate-dependent reduction of $\mathrm{NAD}^{+}$and oxidation of NADH was measured spectrophotometrically at $340 \mathrm{~nm}$. as described in the Methods section. Activities are expressed relative to those with D-I-aminopropan-2-ol, or aminoacetone, measured under appropriate optimum conditions.

Substrate

Activity (\%)

Oxidation

$\begin{array}{lr}\text { D-I-Aminopropan-2-ol } & \text { I00 } \\ \text { DL-Propan-1,2-diol } & 680 \\ \text { DL-I-Bromopropan-2-ol } & 350 \\ \text { meso-Butan-2,3-diol } & 320 \\ \text { Propan-I,3-diol } & 320 \\ \text { DL-I-Fluoropropan-2-ol } & 240 \\ \text { Glycerol } & 220 \\ \text { DL-I-Aminopropan-2,3-diol } & 90 \\ \text { L-I-Aminopropan-2-ol* } & 3 \\ & \\ \text { Aminoacetone Reduction } & 100 \\ \text { Dihydroxyacetone } & 1840 \\ \text { Hydroxyacetone } & 1200 \\ \text { Methylglyoxal } & 960 \\ \text { DL-Acetoin } & 250\end{array}$

* Composition $88 \%$ L-I-aminopropan-2-ol; $12 \%$ D-I-aminopropan-2-ol, used as their L-tartrates. 
concentrations. Activities with each cofactor were not additive. I-Aminopropan-2-ol formation by reduction of aminoacetone was demonstrated chromatographically (see Methods), but the identity of the stereoisomer was not established.

Table 5. Michaelis constants for substrates and cofactors of enzyme acting on D-I-aminopropan-2-ol and aminoacetone

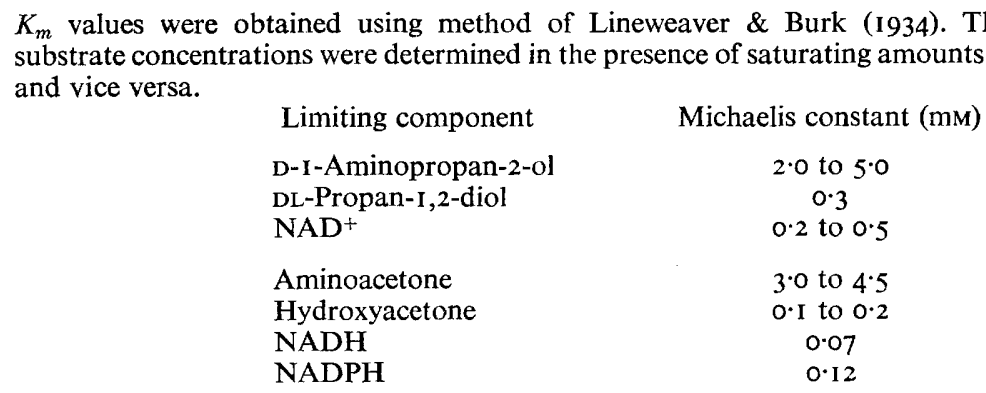

Kinetic behaviour. The effect of D-I-aminopropan-2-ol and $\mathrm{NAD}^{+}$on dehydrogenase activity, at various $\mathrm{NH}_{4}{ }^{+}$concentrations, are shown as double reciprocal plots in Fig. 4. Ammonium ions increased $V_{\max }$ and decreased $K_{m}$ values for the substrate. Michaelis constants for various substrates and cofactors are given in Table 5. Activities in the direction of alcohol oxidation were unaffected by high substrate or cofactor concentration and were not influenced by nucleotides. In contrast, ketone reduction was extremely sensitive to high substrate and cofactor concentrations and was inhibited by ATP but not by ADP or AMP. With NADH at the optimum concentration $(0.4 \mathrm{~mm})$, excess substrate inhibition with aminoacetone and hydroxyacetone occurred above about Io and $\mathrm{I} \cdot 2 \mathrm{~mm}$ respectively. Aminoacetone was reduced twice as rapidly as hydroxyacetone when each was tested at Io $\mathrm{mm}$. With aminoacetone at Io $\mathrm{mm}$, NADH and NADPH were both inhibitory at above about $0.4 \mathrm{mM}$

Inhibition by ATP. Whereas ketone reduction with NADPH was inhibited by $84 \%$ by ATP at $0.3 \mathrm{~mm}$, reduction with NADH was inhibited only $10 \%$. Inhibition by ATP was non-competitive. When the ketone concentration was varied, with NADPH saturating at I mM, the $K_{i}$ for ATP was $0.07 \mathrm{~mm}$. When the cofactor was varied, with ketone constant, the corresponding $K_{i}$ was $0.60 \mathrm{mM}$.

Inhibition by substrate analogues and related compounds. Aminoacetone production from D-I-aminopropan-2-ol was inhibited by substrate analogues (Table 2), many of which were more effective substrates (Table 4). DL-Propan-I,2-diol, meso-butan-2,3diol or DL-I-bromopropan-2-ol (ignoring isomeric forms) caused 91,83 and $57 \%$ inhibition of amino alcohol oxidation when added in equimolar amounts. Inhibition by DL-propan-I,2-diol was found to be competitive ( $K_{i}$ about O-IO $\mathrm{mM}$ ). DL-3-FluoroI-aminopropan-2-ol also acted as both substrate and inhibitor of D-I-aminopropan-2-ol oxidation. L-I-Aminopropan-2-ol was inactive as inhibitor or substrate.

\section{Effect of growth conditions on dehydrogenase activities}

Growth of Escherichia coli on simple synthetic media, containing glucose, succinate, fumarate, malate, aspartate, glycerol, lactate, pyruvate or acetate as sole source of carbon and energy, yielded extracts with low D-I-aminopropan-2-ol dehydrogenase activity. Activity towards all substrates tested was about one-fifth that found in 
extracts of broth-grown organisms. DL-I-Aminopropan-2-ol added as a supplement to either broth or glucose-mineral salts media had no effect on enzyme activity. Of other alternative substrates tested, only hydroxyacetone induced enzyme formation markedly. Six- to tenfold increases occurred when washed suspensions of bacteria grown on glucose were incubated with hydroxyacetone at $150 \mathrm{~mm}$. Dihydroxyacetone and aminoacetone stimulated $2 \cdot 5-$ and $\mathrm{I} \cdot 6$-fold respectively. Similar results were obtained when inducers were added as $0.4 \%$ supplements to cultures of $E$. coli growing on glucose. Escherichia coli was incapable of growth on the hydroxy and

\section{Table 6. Dehydrogenase activities in crude extracts of micro-organisms}

Micro-organisms were grown on nutrient broth and dehydrogenase activities were assayed spectrophotometrically as described in the methods section.

Dehydrogenase activity ( $\mathrm{m} \mu \mathrm{moles} / \mathrm{mg}$. protein/min. at $37^{\circ}$ ) with substrate shown

Micro-organism

Strain

D-I-Amino- L-I-Amino- meso-Butan DL-Propan-

Achromobacter sp. P 6

NCIB IO43I

NCIB 9759

propan-2-ol propan-2-ol

2,3-diol

I,2-diol

Arthrobacter globiformis

NCIB 8061

$2 \cdot 8$

I.5

0.7

NCIB 8524

2.6

B. polymyxa

B. subtilis

Enterobacter cloacae

Erwinia carotovora

Laboratory

$2 \mathrm{I} \cdot \mathrm{O}$

NCIB 8529

NCPPB I 280

$I \cdot 0$

$\mathrm{I} \cdot \mathrm{O}$

NCIB 8II4

NCIB 9481

E. coli, K I 2

E. coli, $\mathrm{K} \mathbf{I} 2$

E. coli, $\mathrm{K} \mathrm{I} 2$

NCIB 9482

NCIB 9483

NCIB 418

NCIB 8017

Laboratory

NCIB 9229

$\mathrm{NCIB} 8858$

DL 8 A

0

$32.0 \quad 13.0$

n.d.

n.d.

$0.3 \quad 136.0 \quad 170.0$

$4^{\circ} 0 \quad 850^{\circ} 0 \quad 700.0$

$3.0 \quad 20.0 \quad 31.0$

$0.3 \quad 185.0 \quad 166.0$

$4 \cdot 1+9 \cdot 9$

$9 \cdot 0$

II $\cdot 4$

$9 \cdot 9$

I0.0

n.d.

n.d.

$35 \cdot 0$

n.d.

n.d.

$8 \cdot 5$

n.d.

n.d.

$8 \cdot 0$

0.3

I.7

0.3

I. 0

n.d.

n.d.

n.d.

$125^{\circ} 0$

n.d.

n.d.

n.d.

34.0

$58 \cdot 0$

$150 \cdot 0$

125.0

$95^{\circ} 0$

n.d.

90.0

n.d.

0.3

$2 \cdot 0$

n.d.

n.d.

* n.d. = not determined.

Table 7. L-Threonine and D-aminopropanol dehydrogenases in micro-organisms used for production of vitamin $B_{12}$

Micro-organisms were grown on peptone-yeast extract medium and enzymes in extracts assayed colorimetrically as described in the Methods section.

Micro-organism

Flavobacterium devorans

Nocardia rugosa

Propionibacterium freudenreichii

P. shermanii

$P$. shermanii

$P$. shermanii

Pseudomonas dentrificans

Streptomyces griseus

S. olivaceus
Dehydrogenase activity

Strain
(NCIB no $)$
8195
8926
5959
5964
5964
8099
8376
9004
8238

Growth conditions

Aerobic

Aerobic

Anaerobic

Aerobic

Anaerobic

Anaerobic

Aerobic

Aerobic

Aerobic (m $\mu$ moles/mg. protein/min. at $37^{\circ}$ )

\begin{tabular}{cr}
\hline D-Aminopropanol & L-Threonine \\
0.4 & $\mathrm{I} \cdot \mathrm{I}$ \\
3.1 & $\mathrm{I} \cdot 7^{\circ}$ \\
0 & 0 \\
3.2 & $\mathrm{I} 9.0$ \\
0 & 0 \\
0 & 0 \\
$\mathrm{I} \cdot \mathrm{I}$ & 3.7 \\
0.8 & 14.0 \\
0.8 & $2 \cdot 0$
\end{tabular}


amino ketones tested, or on the corresponding alcohols. Dehydrogenase activity towards L-I-aminopropan-2-ol was unaffected by hydroxy ketones and analogues, which reduced L-threonine dehydrogenase activity when included in growth media.

\section{Dehydrogenase activities of various micro-organisms}

Extracts of micro-organisms grown on broth were examined for dehydrogenase activities towards several secondary alcohols, including D-I-aminopropan-2-ol. Results are shown in Table 6.

A number of micro-organisms known to produce relatively large amounts of vitamin $\mathrm{B}_{12}$ were examined for L-threonine and D-I-aminopropan-2-ol dehydrogenase. Two of the propionibacter species would grow only anaerobically, although a third was capable of aerobic growth. The results are shown in Table 7 .

\section{DISCUSSION}

The small and slow uptake of radioactivity from $\left[3^{-14} \mathrm{C}\right]-\mathrm{DL}-\mathrm{I}-\mathrm{aminopropan-2-ol}$ by growing cultures of Escherichia coli does not allow us to make any unequivocal statement regarding a biosynthetic role for the D-isomer of the amino alcohol. Neither DL-I-aminopropan-2-ol nor aminoacetone act as a growth substrate or nitrogen source for the $E$. coli in synthetic media, although L-I-aminopropan-2-ol can be readily oxidized to aminoacetone by several intact micro-organisms including $E$. coli. However, the enzyme responsible for oxidation of L-aminopropanol in $E$. coli has been studied (Turner, 1967) and its metabolic significance is uncertain.

The enzyme responsible for D-I-aminopropan-2-ol oxidation in cell-free extracts of Escherichia coli is concluded to be an oxidoreductase of broad specificity in each direction. Evidence includes the constant activity for D-I-aminopropan-2-ol relative to DL-propan-I,2-diol, throughout purification; the inhibition of amino alcohol oxidation by alternative substrates; and induction of activity by hydroxyacetone or dihydroxyacetone but not aminoacetone or I-aminopropan-2-ol. In a comparative study, the highest D-I-aminopropan-2-ol dehydrogenase activity was found in Bacillus polymyxa, known to possess only the D-specific butan-2,3-diol dehydrogenase (Taylor \& Juni, 1960), whereas negligible activity was found in species with the L-specific enzyme, e.g. Enterobacter cloaca (Taylor \& Juni, 1960).

The metabolic function of the enzyme studied in Escherichia coli is not clear, although specificity studies indicate involvement in diol and hydroxyketone metabolism. The acetoin fermentation, however, yielding butan-2,3-diol, is characteristic of Aerobacter aerogenes rather than E. coli, although the butan-2,3-diol-NAD+ oxidoreductase of $A$. aerogenes studied by Taylor \& Juni (I960) was stereospecific for the D-enantiomorphs of the diol substrates tested. Alternatively, the heat-stability of the enzyme, its activation by monovalent cations, $\mathrm{pH}$ optimum and $K_{m}$ for $\mathrm{NAD}^{+}$, all suggests close similarity to the glycerol-NAD ${ }^{+}$oxidoreductases studied in $E$. coli (Asnis \& Brodie, I953) as well as A. aerogenes (Burton, I955; Lin \& Magasanik, 1960; Strickland \& Miller, I968). It should be noted that glycerol but not glycerol-Iphosphate was a substrate for the enzyme described here (Table 4 ). The failure of suspensions of $E$. coli to produce aminoacetone when incubated with D-I-aminopropan-2-ol may well be due to competition by endogenously generated substrates for the oxidoreductase found in extracts. The $K_{m}$ for glycerol found by Asnis \& 
Brodie (I953) was $10 \cdot 7 \mathrm{mM}$, compared with that of $2 \cdot 0$ to $5.0 \mathrm{mM}$ for D-I-aminopropan2-ol reported here.

The significant activity of NADPH as a cofactor for ketone reduction, in contrast to the inactivity of $\mathrm{NADP}^{+}$in the oxidation direction, is noteworthy. It is possible that the oxidoreduction between NADPH and hydroxy- or aminoacetone may be catalysed by a separate contaminating enzyme. Work to establish this has not been carried out. Whether aminoacetone reduction, by either NADH or NADPH, yields the $\mathrm{D}$ - or L-stereoisomer has not been determined.

The enzyme from Escherichia coli K I2, claimed by Dekker \& Swain (I968) to be specific for the reversible oxidoreduction reaction between aminoacetone and D-Iaminopropan-2-ol, appears to differ from the enzyme described here. The enzyme was optimally active with the D-amino alcohol in tris $+\mathrm{HCl}$ buffer between $\mathrm{pH} 8.0$ and $8 \cdot 6$, and inactive with all of a large number of substrate analogues. No activation by monovalent cations or activity with NADPH was reported. The activity with D-I-aminopropan-2-ol in crude extracts was about 14.0 to $14.6 \mathrm{~m} \mu$ moles/mg. protein/ min. at $37^{\circ}$ and $\mathrm{pH} 8.4$ (Dekker \& Swain, 1968). This activity is about the same as that of the non-specific enzyme described here, and found to be present not only in $E$. coli type I, but also in $E$. coli $\mathrm{K} \mathrm{I} 2$ strains.

No convincing evidence for the joint involvement of L-threonine and D-I-aminopropan-2-ol dehydrogenases in the biosynthesis of the vitamin $B_{12}$ was found, in that Propionbacterium species, which are known to produce good yields of the vitamin during anaerobic growth (Mervyn \& Smith, 1964), did not possess either enzymes when grown under such conditions. It now seems clear that in addition to the non-specific nature of the oxidoreductase acting on D-I-aminopropan-2-ol and aminoacetone, L-threonine dehydrogenase may be involved in catabolism yielding glycine and acetyl-CoA (McGilvray \& Morris, I969) as an alternative to aminoacetone.

The interest and support of Professor T. W. Goodwin, F.R.S., in this work is gratefully acknowledged. The authors thank Miss E. Duggan for expert technical assistance, and Miss A. Faulkner for some of the results in Table $\mathrm{r}$. The $\left[3^{-14} \mathrm{C}\right]-\mathrm{DL}-$ I-aminopropan-2-ol used was the valuable gift of Pfizer Ltd (Sandwich, Kent), to whom we are grateful for interest and encouragement. The work was aided by a research grant from the Medical Research Council.

\section{REFERENCES}

AsNis, R. E. \& Brodie, A. F. (1953). A glycerol dehydrogenase from Escherichia coli. Journal of Biological Chemistry 203, I 53-I59.

Burton, R. M. (1955). Glycerol dehydrogenase from Aerobacter aerogenes. Methods in Enzymology I, $397-400$.

Chatelus, G. (1964). La décarboxylation thermique des acides $\alpha$-aminés. Bulletin de la Société Chimique de France I, 2523-2532.

Clark, R. L., Jones, W. H., RaICH, W. J. \& Folkers, K. (I954). Vitamin B 12 XXIII. Resolution of DL-I-amino-2-propanol. Journal of the American Chemical Society 76, 3995-3997.

DeKKer, E. E. \& SwaIN, R. R. (I968). Formation of $\mathrm{D}_{\mathrm{g}}$-I-amino-2-propanol by a highly purified enzyme from Escherichia coli. Biochimica et Biophysica Acta 158, 306-307.

GotTLIEB, S. F. \& MANDEL, M. (I959). Utilization of I-amino-2-propanol by soil bacterium. Canadian Journal of Microbiology 5, 363-368.

Hall, H. H., Benedict, R. G., Wiesen, C. F., Smith, C. E. \& Jackson, R. W. (I953). Studies on vitamin $\mathrm{B}_{12}$ production with Streptomyces olivaceus. Applied Microbiology I, 124-I 35 . 
Higgins, I. J., Pickard, M. A. \& TURner, J. M. (1968). Aminoacetone formation and utilization by pseudomonads grown on DL-r-aminopropan-2-ol. Journal of General Microbiology 54, 105II4.

Karrer, P. \& Klarer, W. (1925). Abbau der I- $\beta$-Oxybuttersäure. Helvetica Chimica Acta 8, 393395.

Krasna, A. I., Rosenblum, C. \& Sprinson, D. B. (1957). The conversion of L-threonine to the $\mathrm{D}_{R}$-I-amino-2-propanol of vitamin $\mathrm{B}_{12}$. Journal of Biological Chemistry 225, 745-750.

Lin, E. C. C. \& MAgasanik, B. (1960). The activation of glycerol dehydrogenase from Aerobacter aerogenes by monovalent cations. Journal of Biological Chemistry 235, 1820-1823.

LINEWEAVER, H. \& BURK, D. (1934). The determination of enzyme dissociation constants. Journal of the American Chemical Society 56, 658-663.

Lowe, D. A. \& Turner, J. M. (I968). Enzymic oxidation of D-I-aminopropan-2-ol by diol dehydrogenases of microbial origin. Biochimica et Biophysica Acta 170, 455-456.

MCGIlvRAY, D. \& Morris, J. G. (1969). Utilization of L-threonine by a species of Arthrobacter. A novel catabolic role for 'aminoacetone synthase'. Biochemical Journal 112, 657-671 .

Mervyn, L. \& Smith, E. L. (1964). The biochemistry of vitamin $\mathrm{B}_{12}$ fermentation. Progress in Industrial Microbiology 5, I53-201.

STrickland, J. E. \& Miller, O. N. (1968). Inhibition of glycerol dehydrogenase from Aerobacter aerogenes by dihydroxyacetone, high ionic strength and monovalent cations. Biochimica et Biophysica Acta 159, 22 1-226.

Sullivan, R. H. (1963). Resolution of racemic aminoisopropanol. U.S. Patent 3, I I 6, 332 (C I-260-584).

TAYLOR, M. B. \& JUNI, E. (1960). Stereoisomeric specificities of 2,3-butanediol dehydrogenases. Biochimica et Biophysica Acta 39, 448-457.

Turner, J. M. (I966). Microbial metabolism of amino ketones. Aminoacetone formation from I-aminopropan-2-ol by a dehydrogenase in Escherichia coli. Biochemical Journal 99, 427-433.

TURNER, J. M. (1967). Microbial metabolism of amino ketones. L-I-Aminopropan-2-ol dehydrogenase and L-threonine dehydrogenase in Escherichia coli. Biochemical Journal 104, I $12-121$. 